Check for updates

Cite this: RSC Adv., 2017, 7, 20582

Received 19th December 2016

Accepted 31st March 2017

DOI: $10.1039 / c 6 r a 28395 k$

rsc.li/rsc-advances

\section{Synthesis and biological evaluation of novel technetium-99m-labeled phenylquinoxaline derivatives as single photon emission computed tomography imaging probes targeting $\beta$-amyloid plaques in Alzheimer's disease $\uparrow$}

\author{
Shimpei likuni, Masahiro Ono, (D)* Keiichi Tanimura, Hiroyuki Watanabe, \\ Masashi Yoshimura and Hideo Saji
}

\begin{abstract}
The development of an imaging probe targeting $\beta$-amyloid (A $\beta$ ) plaques in Alzheimer's disease labeled with technetium-99m, the most commonly used radioisotope for clinical diagnoses, has been strongly anticipated. In this study, we synthesized three novel ${ }^{99 \mathrm{~m}} \mathrm{Tc}$ complexes with the phenylquinoxaline scaffold and evaluated their properties for imaging $A \beta$ plaques. The ${ }^{99 \mathrm{~m}} \mathrm{~T} c$ and corresponding Re complexes were synthesized with bis(aminoethanethiol) (BAT) as a chelating ligand. In a binding affinity assay using recombinant $A \beta(1-42)$ aggregates in vitro, the ${ }^{99 m}$ Tc-labeled $N, N$-dimethylated phenylquinoxaline derivative $\left.{ }^{99 \mathrm{~m}} \mathrm{Tc}-\mathrm{BAT}-\mathrm{C} 3-\mathrm{PQ}-1\right)$ and the corresponding Re complex showed sufficient affinity for $A \beta(1-42)$ aggregates. An in vivo biodistribution study in normal mice revealed that ${ }^{99 \mathrm{~m}} \mathrm{Tc}$-BAT-C3-PQ-1 showed a moderate initial brain uptake and a reasonable clearance from the brain. An ex vivo autoradiographic examination with ${ }^{99 \mathrm{~m}} \mathrm{Tc}-\mathrm{BAT}-\mathrm{C} 3-\mathrm{PQ}-1$ showed the marked labeling of A $\beta$ plaques in brain sections from Tg2576 transgenic mice but not age-matched controls. ${ }^{99 \mathrm{~m}} \mathrm{Tc}$-BAT-C3$P Q-1$ may be a potential single photon emission computed tomography probe for imaging $A \beta$ plaques in Alzheimer's disease.
\end{abstract}

\section{Introduction}

Alzheimer's disease (AD) is the most common neurodegenerative disorder of the brain, with symptoms of memory loss, continuous cognitive decline, and behavioral disturbance. $\mathrm{AD}$ is pathologically characterized by the extracellular deposition of senile plaques consisting of $\beta$-amyloid $(\mathrm{A} \beta)$ and the intracellular deposition of neurofibrillary tangles consisting of hyperphosphorylated tau. $\mathrm{AD}$ is responsible for $60-70 \%$ of dementia in the elderly. ${ }^{1,2}$ Currently, there is no medical treatment that cures or prevents $\mathrm{AD} .{ }^{1}$ Since $\mathrm{A} \beta$ deposition is believed to play a key role in neurodegeneration and begin prior to the onset of the disease, the development of an $\mathrm{A} \beta$-targeted drug for $\mathrm{AD}$ has attracted much interest. ${ }^{3}$ The early diagnosis of AD will be needed for early intervention and appropriate treatment of the disease.

Nuclear medical diagnoses with positron emission tomography (РET) have been utilized as major in vivo imaging

Department of Patho-Functional Bioanalysis, Graduate School of Pharmaceutical Sciences, Kyoto University, 46-29 Yoshida Shimoadachi-cho, Sakyo-ku, Kyoto 606-8501, Japan. E-mail: ono@pharm.kyoto-u.ac.jp; Fax: +81-75-753-4568; Tel: +8175-753-4608

$\dagger$ Electronic supplementary information (ESI) available. See DOI: 10.1039/c6ra28395k modalities to carry out noninvasive diagnosis. Over the past few decades, research on the imaging of $A \beta$ aggregates in $A D$ brains with PET has made marked progress. Many clinical studies using $\left[{ }^{11} \mathrm{C}\right] \mathrm{PIB}$, which is the main $\mathrm{A} \beta$ imaging probe, have proved this utility for AD diagnosis. ${ }^{4-7}$ More recently, $\left[{ }^{18} \mathrm{~F}\right]$ florbetapir (Amyvid), ${ }^{7-9}\left[{ }^{18} \mathrm{~F}\right]$ flutemetamol (Vizamyl), ${ }^{4,10,11}$ and $\left[{ }^{18} \mathrm{~F}\right]$ florbetaben (Neuraceq) ${ }^{7,12,13}$ have been approved by the U.S. Food and Drug Administration for clinical AD diagnosis. However, the routine clinical use of PET probes labeled with ${ }^{11} \mathrm{C}$ and ${ }^{18} \mathrm{~F}$ might be limited by their short physical half-lives $\left(t_{1 / 2}=\right.$ 20 and $110 \mathrm{~min}$, respectively).

To address the problem of an increase in $\mathrm{AD}$ patients in the world, more generally versatile $A \beta$ imaging with single photon emission computed tomography (SPECT) is needed. In exploratory research on the development of $A \beta$ imaging probes for SPECT, a number of radioiodinated compounds with affinity for $\mathrm{A} \beta$ aggregates have been reported. ${ }^{14-17}$ Among them, a recent report suggested that $\left[{ }^{123} \mathrm{I}\right] \mathrm{ABC} 577$ may be a clinically useful tracer for SPECT imaging of $\mathrm{A} \beta$ plaques in the brains of $\mathrm{AD}$ patients. ${ }^{18}$

Among clinically utilized radioisotopes for SPECT, ${ }^{99 \mathrm{~m}} \mathrm{Tc}$ is the most commonly used in nuclear medical diagnoses for several reasons, including easy production by a ${ }^{99} \mathrm{Mo} /{ }^{99 \mathrm{~m}} \mathrm{Tc}$ generator, its physical half-life $(6.01 \mathrm{~h})$ being compatible with 
<smiles>CN(C)c1ccc(-c2cnc3cc(Br)ccc3n2)cc1</smiles><smiles>CN(C)c1ccc(-c2cnc3cc(OCC[18F])ccc3n2)cc1</smiles><smiles></smiles>

Fig. 1 Chemical structures of the radioiodinated or radiofluorinated phenylquinoxaline derivatives reported in our previous study, and ${ }^{99 \mathrm{~m}} \mathrm{Tc}$ labeled phenylquinoxaline derivatives in the present study.

the biological localization, and its $\gamma$-ray energy $(141 \mathrm{keV})$ suitable for in vivo imaging. Thus, the development of ${ }^{99 \mathrm{~m}} \mathrm{Tc}$-labeled $\mathrm{A} \beta$ imaging probes will provide simple, convenient, and widespread SPECT-based imaging methods for the detection of $A \beta$ plaques in the living brain.

To develop useful ${ }^{99 \mathrm{~m}}$ Tc-labeled imaging agents targeting $\mathrm{A} \beta$ depositions in AD brains, compact and neutral ${ }^{99 \mathrm{~m}} \mathrm{Tc}$-labeled ligands have been reported, such as derivatives of biphenyl, ${ }^{19}$ phenylbenzothiazole, ${ }^{20}$ chalcone ${ }^{21}$ flavone, aurone, ${ }^{22}$ curcumin, ${ }^{23}$ arylbenzofuran, ${ }^{24,25}$ dibenzylideneacetone, ${ }^{26}$ and arylbenzoxazole. ${ }^{27,28}$ However, there have been no reports on the development of clinically useful ${ }^{99 \mathrm{~m}} \mathrm{Tc}$-labeled probes due to either low affinity for $A \beta$ aggregates or low brain uptake.

We previously reported phenylquinoxaline derivatives labeled with ${ }^{125} \mathrm{I}$ or ${ }^{18} \mathrm{~F}$ targeting $\mathrm{A} \beta$ in $\mathrm{AD}$ brains (Fig. 1). ${ }^{29-31}$ These derivatives displayed high binding affinity for $\mathrm{A} \beta$ aggregates with $K_{\mathrm{i}}$ values in the $\mathrm{nM}$ range and showed specific labeling of $\mathrm{A} \beta$ plaques in sections of brain tissue from $\mathrm{AD}$ patients. Notably, $\left[{ }^{18} \mathrm{~F}\right] \mathrm{PQ}-6$ showed an excellent $K_{\mathrm{i}}$ value $(0.895$ $\mathrm{nM}$ ) and intensive specific labeling of $\mathrm{A} \beta$ in the $\mathrm{AD}$ brain section. ${ }^{30}$ These properties were superior to those of clinically used $\mathrm{A} \beta$ imaging probes, such as $\left[{ }^{11} \mathrm{C}\right] \mathrm{PIB}$ and $\left[{ }^{18} \mathrm{~F}\right]$ florbetapir ( $K_{\mathrm{i}}=9.00$ and $12.8 \mathrm{nM}$, respectively). Based on these encouraging results, we designed novel ${ }^{99 \mathrm{~m}}$ Tc-labeled $\mathrm{A} \beta$ imaging probes with the scaffold of phenylquinoxaline (Fig. 1). Unlike radiohalogens, a chelating ligand is necessary for the introduction of metal ${ }^{99 \mathrm{~m}} \mathrm{Tc}$ to the organic molecule. Considering the permeability at the blood-brain barrier (BBB), we selected bis(aminoethanethiol) (BAT) as a compact chelating ligand to form a neutral ${ }^{99 \mathrm{~m}} \mathrm{Tc}$ complex. We herein synthesized novel ${ }^{99 \mathrm{~m}} \mathrm{Tc}$ complexes based on phenylquinoxaline with BAT and evaluated their biological properties as potential SPECT probes targeting $\mathrm{A} \beta$ plaques in $\mathrm{AD}$.

\section{Materials and methods}

\section{General}

All reagents were obtained commercially and used without further purification unless otherwise indicated. $\mathrm{Na}^{99 \mathrm{~m}} \mathrm{TcO}_{4}$ was purchased from Nihon Medi-Physics Co., Ltd. (Tokyo, Japan) or obtained from a commercial ${ }^{99} \mathrm{Mo} /{ }^{99 \mathrm{~m}} \mathrm{Tc}$ generator (UltraTechne Kow; FUJIFILM RI Pharma Co., Ltd., Tokyo, Japan). W-Prep 2XY (Yamazen, Osaka, Japan) was used for silica gel column chromatography on a Hi Flash silica gel column $(40 \mu \mathrm{m}$,
$60 \AA$, Yamazen). ${ }^{1} \mathrm{H}$ NMR spectra were recorded on a JNMECS400 (JEOL, Tokyo, Japan) with tetramethylsilane (TMS) as an internal standard. Coupling constants are reported in Hertz. Multiplicity was defined as singlet (s), doublet (d), triplet (t), or multiplet $(\mathrm{m})$. Mass spectra were obtained on a SHIMADZU LCMS-2020 EV (SHIMADZU, Kyoto, Japan). High-resolution mass spectrometry (HRMS) was conducted with a LCMS-ITTOF (SHIMADZU). Reversed-phase high-performance liquid chromatography (RP-HPLC) was performed with a Shimadzu system (SHIMADZU, an LC-20AT pump with an SPD-20A UV detector, $\lambda=254 \mathrm{~nm}$ ) with a Cosmosil $\mathrm{C}_{18}$ column (Nacalai Tesque, Kyoto, Japan, 5C 18 -AR-II, $4.6 \times 150 \mathrm{~mm}$ ) delivered at a flow rate of $1.0 \mathrm{~mL} \mathrm{~min}^{-1}$ using a solvent of $\mathrm{H}_{2} \mathrm{O} / \mathrm{MeCN}[11: 9$ (0 $\mathrm{min})$ to $1: 3(30 \mathrm{~min})]$ as the mobile phase.

\section{Animals}

Animal experiments were conducted in accordance with our institutional guidelines and were approved by the Kyoto University Animal Care Committee. Male ddY mice were purchased from Japan SLC, Inc. (Shizuoka, Japan). Female Tg2576 and wild-type mice were purchased from Taconic Farms, Inc. (New York, U.S.A.). Animals were fed standard chow and had free access to water. All efforts were made to minimize suffering.

\section{Chemistry}

Synthesis of $N$-methyl-4-(4,4,5,5-tetramethyl-1,3,2dioxaborolan-2-yl)aniline (1). To a suspension of 4-(4,4,5,5tetramethyl-1,3,2-dioxaborolan-2-yl)aniline $(1.10 \mathrm{~g}, 5.0 \mathrm{mmol})$ and paraformaldehyde $(901 \mathrm{mg}, 30 \mathrm{mmol})$ in $\mathrm{MeOH}(10 \mathrm{~mL})$ was slowly added sodium methoxide $(5 \mathrm{M}$ in $\mathrm{MeOH}, 4.0 \mathrm{~mL}, 20$ $\mathrm{mmol}$ ). The mixture was heated to reflux for $1 \mathrm{~h}$ and then allowed to cool to $0{ }^{\circ} \mathrm{C} . \mathrm{NaBH}_{4}(946 \mathrm{mg}, 25 \mathrm{mmol})$ was added gently. The reaction mixture was brought to reflux again for $1.5 \mathrm{~h}$ and then quenched with saturated $\mathrm{NaHCO}_{3}$ (aq.). After the addition of $\mathrm{H}_{2} \mathrm{O}$ $(50 \mathrm{~mL})$, the mixture was extracted with $\mathrm{CHCl}_{3}(50 \mathrm{~mL} \times 2)$. The organic phases were combined and dried over $\mathrm{MgSO}_{4}$. Evaporation of the solvent afforded a residue, which was purified by silica gel chromatography (AcOEt/hexane $=1: 5$ ) to give $302 \mathrm{mg}$ of 1 (26\%). ${ }^{1} \mathrm{H}$ NMR $\left(400 \mathrm{MHz}, \mathrm{CDCl}_{3}\right) \delta 7.55(\mathrm{~d}, J=6.8 \mathrm{~Hz}, 2 \mathrm{H}), 6.45$ (d, $J=6.8 \mathrm{~Hz}, 2 \mathrm{H}), 3.86$ (s, broad, 1H), $2.69(\mathrm{~s}, 3 \mathrm{H}), 1.21(\mathrm{~s}, 12 \mathrm{H})$. MS (ESI): $m / z$ calculated for $\mathrm{C}_{13} \mathrm{H}_{21} \mathrm{BNO}_{2}{ }^{+}[\mathrm{M}+\mathrm{H}]^{+}, 234$; found, 234. 
Synthesis of tert-butyl(2-((3-bromopropyl)(2-(tritylthio)ethyl) amino)ethyl)(2-(tritylthio)ethyl)carbamate (2). A solution of TrtBoc-BAT (1.53 g, $2.0 \mathrm{mmol})$, 1,3-dibromopropane (223 $\mu \mathrm{L}, 2.2$ mmol), $N, N$-diisopropylethylamine $(697 \mu \mathrm{L}, 4.0 \mathrm{mmol})$ in dimethylformamide (DMF) $(5 \mathrm{~mL})$ was stirred at $90{ }^{\circ} \mathrm{C}$ for $3 \mathrm{~h}$. After cooling to room temperature, the mixture was concentrated. The residue was purified by silica gel chromatography $($ AcOEt/hexane $=1: 5)$ to give $454 \mathrm{mg}$ of $2(26 \%) .{ }^{1} \mathrm{H}$ NMR $(400$ $\left.\mathrm{MHz}, \mathrm{CDCl}_{3}\right) \delta$ 7.41-7.39 (m, 12H), 7.29-7.23 (m, 12H), 7.22$7.17(\mathrm{~m}, 6 \mathrm{H}), 3.32(\mathrm{~s}, 2 \mathrm{H}), 3.00-2.82(\mathrm{~m}, 4 \mathrm{H}), 2.38-2.16(\mathrm{~m}, 10 \mathrm{H})$, 1.76-1.70 (m, 2H), $1.37(\mathrm{~s}, 9 \mathrm{H})$. MS (ESI): $\mathrm{m} / \mathrm{z}$ calculated for $\mathrm{C}_{52} \mathrm{H}_{58} \mathrm{BrN}_{2} \mathrm{O}_{2} \mathrm{~S}_{2}^{+}[\mathrm{M}+\mathrm{H}]^{+}$, 887; found, 887 .

Synthesis of 2-chloroquinoxalin-6-ol (3). Compound 3 was synthesized from 2-chloro-6-methoxyquinoxaline according to a previous report. ${ }^{30}$

Synthesis of 2-(4-(dimethylamino)phenyl)quinoxalin-6-ol (4). To a solution of $3(181 \mathrm{mg}, 1.0 \mathrm{mmol})$ and $N, N$-dimethyl-4(4,4,5,5-tetramethyl-1,3,2-dioxaborolan-2-yl)aniline (272 mg, 1.1 mmol) in $2 \mathrm{M} \mathrm{Na}_{2} \mathrm{CO}_{3}$ (aq.)/dioxane $(1: 1,16 \mathrm{~mL})$ was added $\mathrm{Pd}\left(\mathrm{PPh}_{3}\right)_{4}(115 \mathrm{mg}, 0.10 \mathrm{mmol})$. The mixture was heated to reflux for $1 \mathrm{~h}$. After cooling to room temperature, $\mathrm{H}_{2} \mathrm{O}(50 \mathrm{~mL})$ was added. After the extraction of the mixture with AcOEt $(50 \mathrm{~mL} \times$ 2), the organic phases were combined and dried over $\mathrm{MgSO}_{4}$. Evaporation of the solvent afforded a residue, which was purified by silica gel chromatography $\left(\mathrm{CHCl}_{3} / \mathrm{MeOH}=10: 1\right)$ to give $236 \mathrm{mg}$ of $4(89 \%) .{ }^{1} \mathrm{H}$ NMR (400 MHz, DMSO- $\left.d_{6}\right) \delta 9.31(\mathrm{~s}, 1 \mathrm{H})$, $8.13(\mathrm{~d}, J=7.6 \mathrm{~Hz}, 2 \mathrm{H}), 7.87(\mathrm{~d}, J=8.4 \mathrm{~Hz}, 1 \mathrm{H}), 7.35(\mathrm{~d}, J=$ $8.4 \mathrm{~Hz}, 1 \mathrm{H}), 7.23(\mathrm{~s}, 1 \mathrm{H}), 6.86(\mathrm{~d}, J=7.6 \mathrm{~Hz}, 2 \mathrm{H}), 3.01(\mathrm{~s}, 6 \mathrm{H}) . \mathrm{MS}$ (ESI): $m / z$ calculated for $\mathrm{C}_{16} \mathrm{H}_{16} \mathrm{~N}_{3} \mathrm{O}^{+}[\mathrm{M}+\mathrm{H}]^{+}, 266$; found, 266 .

Synthesis of 2-(4-(methylamino)phenyl)quinoxalin-6-ol (5). To a solution of $3(181 \mathrm{mg}, 1.0 \mathrm{mmol})$ and $1(256 \mathrm{mg}, 1.1 \mathrm{mmol})$ in $2 \mathrm{M} \mathrm{Na}_{2} \mathrm{CO}_{3}$ (aq.)/dioxane $(1: 2,30 \mathrm{~mL})$ was added $\mathrm{Pd}\left(\mathrm{PPh}_{3}\right)_{4}$ (115 mg, $0.10 \mathrm{mmol}$ ). The mixture was heated to reflux for $30 \mathrm{~min}$. After cooling to room temperature, $\mathrm{H}_{2} \mathrm{O}(200 \mathrm{~mL})$ was added. The mixture was extracted with AcOEt $(100 \mathrm{~mL} \times 2)$. The organic phases were combined and dried over $\mathrm{MgSO}_{4}$. Evaporation of the solvent afforded a residue, which was purified by silica gel chromatography (AcOEt/hexane $=1: 1$ ) to give $153 \mathrm{mg}$ of $5(61 \%) .{ }^{1} \mathrm{H}$ NMR $\left(400 \mathrm{MHz}, \mathrm{CDCl}_{3}\right) \delta 9.06(\mathrm{~s}, 1 \mathrm{H}), 7.98(\mathrm{~d}, J=$ $8.8 \mathrm{~Hz}, 2 \mathrm{H}), 7.90(\mathrm{~d}, J=9.2 \mathrm{~Hz}, 1 \mathrm{H}), 7.37(\mathrm{~s}, 1 \mathrm{H}), 7.33-7.29(\mathrm{~m}$, $1 \mathrm{H}), 6.70(\mathrm{~d}, J=8.8 \mathrm{~Hz}, 2 \mathrm{H}), 2.90$ (s, 3H). MS (ESI): $\mathrm{m} / \mathrm{z}$ calculated for $\mathrm{C}_{15} \mathrm{H}_{14} \mathrm{~N}_{3} \mathrm{O}^{+}[\mathrm{M}+\mathrm{H}]^{+}$, 252; found, 252 .

Synthesis of 2-(4-aminophenyl)quinoxalin-6-ol (6). To a solution of $3(361 \mathrm{mg}, 2.0 \mathrm{mmol})$ and 4-(4,4,5,5-tetramethyl1,3,2-dioxaborolan-2-yl)aniline (482 $\mathrm{mg}, 2.2 \mathrm{mmol})$ in $2 \mathrm{M}$ $\mathrm{Na}_{2} \mathrm{CO}_{3}$ (aq.)/dioxane $(1: 1,24 \mathrm{~mL})$ was added $\mathrm{Pd}\left(\mathrm{PPh}_{3}\right)_{4}$ ( $231 \mathrm{mg}, 0.20 \mathrm{mmol}$ ). The mixture was heated to reflux for $2 \mathrm{~h}$. After cooling to room temperature, $\mathrm{H}_{2} \mathrm{O}(60 \mathrm{~mL})$ was added. The mixture was extracted with AcOEt $(60 \mathrm{~mL} \times 2)$. The organic phases were combined and dried over $\mathrm{MgSO}_{4}$. Evaporation of the solvent afforded a residue, which was purified by silica gel chromatography (AcOEt/hexane $=3: 1$ ) to give $49 \mathrm{mg}$ of 6 (10\%). ${ }^{1} \mathrm{H}$ NMR $\left(400 \mathrm{MHz}, \mathrm{CD}_{3} \mathrm{OD}\right) \delta 9.14(\mathrm{~s}, 1 \mathrm{H}), 7.94(\mathrm{~d}, J=$ $8.8 \mathrm{~Hz}, 2 \mathrm{H}), 7.91(\mathrm{~d}, J=9.2 \mathrm{~Hz}, 1 \mathrm{H}), 7.37$ (dd, $J=9.2,2.8 \mathrm{~Hz}$, $1 \mathrm{H}), 7.26(\mathrm{~d}, J=2.8 \mathrm{~Hz}, 1 \mathrm{H}), 6.83(\mathrm{~d}, J=8.8 \mathrm{~Hz}, 2 \mathrm{H}) . \mathrm{MS}(\mathrm{ESI}): m /$ $z$ calculated for $\mathrm{C}_{14} \mathrm{H}_{12} \mathrm{~N}_{3} \mathrm{O}^{+}[\mathrm{M}+\mathrm{H}]^{+}, 238$; found, 238 .
Synthesis of tert-butyl(2-((3-)(2-(4-(dimethylamino)phenyl) quinoxalin-6-yl)oxy)propyl)(2-(tritylthio)ethyl)amino)ethyl)(2(tritylthio)ethyl)carbamate (7). A solution of $2(100 \mathrm{mg}, 0.11$ $\mathrm{mmol}), 4(73 \mathrm{mg}, 0.26 \mathrm{mmol})$, and cesium carbonate $(171 \mathrm{mg}$, $0.52 \mathrm{mmol})$ in DMF $(5 \mathrm{~mL})$ was stirred at $70{ }^{\circ} \mathrm{C}$ for $2 \mathrm{~h}$. After being neutralized with saturated $\mathrm{NH}_{4} \mathrm{Cl}$ (aq.), the mixture was extracted with $\mathrm{CHCl}_{3}(50 \mathrm{~mL} \times 2)$. The organic phases were combined and dried over $\mathrm{MgSO}_{4}$. After being evaporated to dryness, the residue was purified by silica gel chromatography (AcOEt/hexane $=1: 1)$ to give $87 \mathrm{mg}$ of $7(62 \%) .{ }^{1} \mathrm{H}$ NMR $(400$ $\left.\mathrm{MHz}, \mathrm{CDCl}_{3}\right) \delta 9.18(\mathrm{~s}, 1 \mathrm{H}), 8.09(\mathrm{~d}, J=8.8 \mathrm{~Hz}, 2 \mathrm{H}), 7.92(\mathrm{~d}, J=$ $9.2 \mathrm{~Hz}, 1 \mathrm{H}), 7.40-7.37(\mathrm{~m}, 14 \mathrm{H}), 7.30-7.27(\mathrm{~m}, 6 \mathrm{H}), 7.23-7.16$ $(\mathrm{m}, 12 \mathrm{H}), 6.85(\mathrm{~d}, J=8.8 \mathrm{~Hz}, 2 \mathrm{H}), 4.03(\mathrm{t}, J=6.0 \mathrm{~Hz}, 2 \mathrm{H}), 3.07(\mathrm{~s}$, $6 \mathrm{H}), 2.95-2.84(\mathrm{~m}, 4 \mathrm{H}), 2.41-2.25(\mathrm{~m}, 10 \mathrm{H}), 1.76(\mathrm{t}, J=6.4 \mathrm{~Hz}$, $2 \mathrm{H}), 1.37(\mathrm{~s}, 9 \mathrm{H})$. MS (ESI): $m / z$ calculated for $\mathrm{C}_{68} \mathrm{H}_{72} \mathrm{~N}_{5} \mathrm{O}_{3} \mathrm{~S}_{2}{ }^{+}[\mathrm{M}$ $+\mathrm{H}]^{+}, 1070$; found, 1070 .

Synthesis of tert-butyl(2-((3-((2-(4-(methylamino)phenyl) quinoxalin-6-yl)oxy)propyl)(2-(tritylthio)ethyl)amino)ethyl)(2(tritylthio)ethyl)carbamate (8). A solution of $2(100 \mathrm{mg}, 0.11$ $\mathrm{mmol}), 5(66 \mathrm{mg}, 0.26 \mathrm{mmol})$, and cesium carbonate $(171 \mathrm{mg}$, $0.52 \mathrm{mmol}$ ) in DMF ( $5 \mathrm{~mL}$ ) was stirred at $70^{\circ} \mathrm{C}$ for $30 \mathrm{~min}$. After being neutralized with saturated $\mathrm{NH}_{4} \mathrm{Cl}$ (aq.), the mixture was extracted with $\mathrm{CHCl}_{3}(50 \mathrm{~mL} \times 2)$. The organic phases were combined and dried over $\mathrm{MgSO}_{4}$. After being evaporated to dryness, the residue was purified by silica gel chromatography (AcOEt/hexane $=1: 1)$ to give $38 \mathrm{mg}$ of $8(27 \%) .{ }^{1} \mathrm{H}$ NMR $(400$ $\left.\mathrm{MHz}, \mathrm{CDCl}_{3}\right) \delta 9.17(\mathrm{~s}, 1 \mathrm{H}), 8.05(\mathrm{~d}, J=8.4 \mathrm{~Hz}, 2 \mathrm{H}), 7.92(\mathrm{~d}, J=$ $8.8 \mathrm{~Hz}, 1 \mathrm{H}), 7.40-7.37(\mathrm{~m}, 12 \mathrm{H}), 7.30-7.28(\mathrm{~m}, 6 \mathrm{H}), 7.23-7.16$ $(\mathrm{m}, 14 \mathrm{H}), 6.74(\mathrm{~d}, J=8.4 \mathrm{~Hz}, 2 \mathrm{H}), 4.03(\mathrm{t}, J=6.4 \mathrm{~Hz}, 2 \mathrm{H}), 3.02-$ $2.96(\mathrm{~m}, 2 \mathrm{H}), 2.92(\mathrm{~s}, 3 \mathrm{H}), 2.42-2.25(\mathrm{~m}, 12 \mathrm{H}), 1.77(\mathrm{t}, J=6.4 \mathrm{~Hz}$, $2 \mathrm{H}$ ), 1.37 (s, 9H). MS (ESI): $m / z$ calculated for $\mathrm{C}_{67} \mathrm{H}_{70} \mathrm{~N}_{5} \mathrm{O}_{3} \mathrm{~S}_{2}{ }^{+}[\mathrm{M}$ $+\mathrm{H}]^{+}$, 1056; found, 1056.

Synthesis of Re-BAT-C3-PQ-1 (9). To a solution of 7 (44 mg, $0.041 \mathrm{mmol}$ ) in trifluoroacetic acid (TFA) $(4 \mathrm{~mL})$ was added triethylsilane $(0.2 \mathrm{~mL})$, the solution was mixed, and then the solvents were removed under a stream of argon gas. The residue was resolved in a mixed solvent of $\mathrm{CH}_{2} \mathrm{Cl}_{2} / \mathrm{MeOH}(10: 1,22 \mathrm{~mL})$, to which were added $\mathrm{ReOCl}_{3}\left(\mathrm{PPh}_{3}\right)_{2}(70 \mathrm{mg}, 0.084 \mathrm{mmol})$ and $1 \mathrm{M}$ AcONa in $\mathrm{MeOH}(4 \mathrm{~mL})$. The reaction mixture was heated to reflux for $8 \mathrm{~h}$. After cooling to room temperature, $\mathrm{CHCl}_{3}(60 \mathrm{~mL})$ was added and filtered. Evaporation of the filtrate gave a residue, which was purified by silica gel chromatography $\left(\mathrm{CHCl}_{3} / \mathrm{MeOH}=10: 1\right)$ and then RP-HPLC $\left(\mathrm{MeCN} / \mathrm{H}_{2} \mathrm{O}=1: 1\right)$ to give $24 \mathrm{mg}$ of $9(84 \%) .{ }^{1} \mathrm{H}$ NMR $\left(400 \mathrm{MHz}, \mathrm{DMSO}-d_{6}\right) \delta 9.42(\mathrm{~s}$, $1 \mathrm{H}), 8.17(\mathrm{~d}, J=8.8 \mathrm{~Hz}, 2 \mathrm{H}), 7.95(\mathrm{~d}, J=8.4 \mathrm{~Hz}, 1 \mathrm{H}), 7.49(\mathrm{dd}, J=$ $8.4,2.4 \mathrm{~Hz}, 1 \mathrm{H}), 7.46(\mathrm{~d}, J=2.4 \mathrm{~Hz}, 1 \mathrm{H}), 6.86(\mathrm{~d}, J=8.8 \mathrm{~Hz}, 2 \mathrm{H})$, $4.30(\mathrm{t}, J=6.4 \mathrm{~Hz}, 2 \mathrm{H}), 4.18-3.83(\mathrm{~m}, 4 \mathrm{H}), 3.64-3.16(\mathrm{~m}, 6 \mathrm{H})$, $3.02(\mathrm{~s}, 6 \mathrm{H}), 2.72-1.68(\mathrm{~m}, 6 \mathrm{H})$. HRMS (ESI): $\mathrm{m} / \mathrm{z}$ calculated for $\mathrm{C}_{25} \mathrm{H}_{32} \mathrm{~N}_{5} \mathrm{NaO}_{2}{ }^{187} \mathrm{ReS}_{2}{ }^{+}[\mathrm{M}+\mathrm{Na}]^{+}$, 708.1447; found, 708.1446.

Synthesis of Re-BAT-C3-PQ-2 (10). To a solution of $8(20 \mathrm{mg}$, $0.019 \mathrm{mmol})$ in TFA $(8 \mathrm{~mL})$ was added triethylsilane $(0.4 \mathrm{~mL})$, the solution was mixed, and then the solvents were removed under a stream of argon gas. The residue was resolved in a mixed solvent of $\mathrm{CH}_{2} \mathrm{Cl}_{2} / \mathrm{MeOH}(10: 1,22 \mathrm{~mL})$, to which were added $\mathrm{ReOCl}_{3}\left(\mathrm{PPh}_{3}\right)_{2}(32 \mathrm{mg}, 0.038 \mathrm{mmol})$ and $1 \mathrm{M} \mathrm{AcONa}$ in $\mathrm{MeOH}(4 \mathrm{~mL})$. The reaction mixture was heated to reflux for $2 \mathrm{~h}$. 
After cooling to room temperature, $\mathrm{H}_{2} \mathrm{O}(50 \mathrm{~mL})$ was added. The mixture was extracted with $\mathrm{CHCl}_{3}(50 \mathrm{~mL} \times 2)$ and dried over $\mathrm{MgSO}_{4}$. Evaporation of the solution gave a residue, which was purified by silica gel chromatography $\left(\mathrm{CHCl}_{3} / \mathrm{MeOH}=10: 1\right)$ and then RP-HPLC $\left(\mathrm{MeCN} / \mathrm{H}_{2} \mathrm{O}=1: 1\right)$ to give $5 \mathrm{mg}$ of $\mathbf{1 0}(39 \%)$. ${ }^{1} \mathrm{H}$ NMR (400 MHz, DMSO- $\left.d_{6}\right) \delta 9.38(\mathrm{~s}, 1 \mathrm{H}), 8.10(\mathrm{~d}, J=8.8 \mathrm{~Hz}$, $2 \mathrm{H}), 7.93(\mathrm{~d}, J=8.4 \mathrm{~Hz}, 1 \mathrm{H}), 7.48(\mathrm{dd}, J=8.4,2.4 \mathrm{~Hz}, 1 \mathrm{H}), 7.45$ $(\mathrm{d}, J=2.4 \mathrm{~Hz}, 1 \mathrm{H}), 6.69(\mathrm{~d}, J=8.8 \mathrm{~Hz}, 2 \mathrm{H}), 4.30(\mathrm{t}, J=6.4 \mathrm{~Hz}$, $2 \mathrm{H}), 4.14-3.82(\mathrm{~m}, 4 \mathrm{H}), 3.64-3.17(\mathrm{~m}, 6 \mathrm{H}), 2.76$ (s, 3H), 2.72-1.68 (m, 6H). HRMS (ESI): $m / z$ calculated for $\mathrm{C}_{24} \mathrm{H}_{31} \mathrm{~N}_{5} \mathrm{O}_{2}{ }^{187} \mathrm{ReS}_{2}{ }^{+}[\mathrm{M}$ $+\mathrm{H}]^{+}, 672.1471$; found, 672.1475.

Synthesis of 4-(6-(3-bromopropoxy)quinoxalin-2-yl)aniline (11). To a solution of 6 (49 mg, $0.21 \mathrm{mmol})$ and 1,3-dibromopropane $(84 \mu \mathrm{L}, 0.83 \mathrm{mmol})$ in $\mathrm{MeCN}(10 \mathrm{~mL})$ was added $\mathrm{K}_{2} \mathrm{CO}_{3}$ ( $85 \mathrm{mg}, 0.62 \mathrm{mmol}$ ). The mixture was heated to reflux for $2 \mathrm{~h}$. After cooling to room temperature, $\mathrm{H}_{2} \mathrm{O}(60 \mathrm{~mL})$ was added. The mixture was extracted with AcOEt $(60 \mathrm{~mL} \times 2)$. The organic phases were combined and dried over $\mathrm{MgSO}_{4}$. Evaporation of the solvent afforded a residue, which was purified by silica gel chromatography (AcOEt/hexane $=3: 1$ ) to give $46 \mathrm{mg}$ of 11 (62\%). ${ }^{1} \mathrm{H}$ NMR (400 MHz, $\left.\mathrm{CDCl}_{3}\right) \delta 9.18(\mathrm{~s}, 1 \mathrm{H}), 8.01(\mathrm{~d}, J=$ $8.4 \mathrm{~Hz}, 2 \mathrm{H}), 7.98(\mathrm{~d}, J=10.0 \mathrm{~Hz}, 1 \mathrm{H}), 7.42-7.35(\mathrm{~m}, 2 \mathrm{H}), 6.83$ (d, $J=8.4 \mathrm{~Hz}, 2 \mathrm{H}), 4.28(\mathrm{t}, J=6.0 \mathrm{~Hz}, 2 \mathrm{H}), 3.66(\mathrm{t}, J=6.4 \mathrm{~Hz}, 2 \mathrm{H})$, $2.42(\mathrm{t}, J=6.4 \mathrm{~Hz}, 2 \mathrm{H})$. MS (ESI): $\mathrm{m} / z$ calculated for $\mathrm{C}_{18} \mathrm{H}_{16} \mathrm{BrN}_{3} \mathrm{O}^{+}[\mathrm{M}+\mathrm{H}]^{+}$, 358; found, 358 .

Synthesis of tert-butyl(2-((3-)(2-(4-aminophenyl)quinoxalin6-yl)oxy)propyl)(2-(tritylthio)ethyl)amino)ethyl)(2-(tritylthio) ethyl)carbamate (12). To a solution of 11 (46 $\mathrm{mg}, 0.13 \mathrm{mmol}$ ) and Trt-Boc-BAT (98 mg, $0.13 \mathrm{mmol}$ ) in DMF (15 mL) was added $N, N$-diisopropylethylamine $(45 \mu \mathrm{L}, 0.26 \mathrm{mmol})$. The mixture was stirred at $110{ }^{\circ} \mathrm{C}$ for $2 \mathrm{~h}$. After cooling to room temperature, $\mathrm{H}_{2} \mathrm{O}$ $(60 \mathrm{~mL})$ was added. The mixture was extracted with AcOEt/ hexane $(1: 1,60 \mathrm{~mL} \times 2)$. The organic phases were combined and dried over $\mathrm{MgSO}_{4}$. Evaporation of the solvent afforded a residue, which was purified by silica gel chromatography (AcOEt/hexane $=3: 1$ ) to give $18 \mathrm{mg}$ of $12(13 \%) .{ }^{1} \mathrm{H}$ NMR (400 $\left.\mathrm{MHz} \mathrm{CDCl}_{3}\right) \delta 9.17(\mathrm{~s}, 1 \mathrm{H}), 8.01(\mathrm{~d}, J=8.4 \mathrm{~Hz}, 2 \mathrm{H}), 7.93(\mathrm{~d}, J=$ $9.2 \mathrm{~Hz}, 1 \mathrm{H}), 7.41-7.36,(\mathrm{~m}, 14 \mathrm{H}), 7.33-7.27$ (m, 4H), 7.24-7.15 (m, 12H), 4.15-3.80 (m, 4H), 2.42-2.20 (m, 10H). MS (ESI): $m / z$ calculated for $\mathrm{C}_{66} \mathrm{H}_{68} \mathrm{~N}_{5} \mathrm{O}_{3} \mathrm{~S}_{2}{ }^{+}[\mathrm{M}+\mathrm{H}]^{+}$, 1043; found, 1043.

Synthesis of Re-BAT-C3-PQ-3 (13). To a solution of $12(11 \mathrm{mg}$, $0.011 \mathrm{mmol})$ in TFA $(2 \mathrm{~mL})$ was added triethylsilane $(0.1 \mathrm{~mL})$, the solution was mixed, and then the solvents were removed under a stream of argon gas. The residue was resolved in a mixed solvent of $\mathrm{CH}_{2} \mathrm{Cl}_{2} / \mathrm{MeOH}(10: 1,5 \mathrm{~mL})$, to which were added $\mathrm{ReOCl}_{3}\left(\mathrm{PPh}_{3}\right)_{2}(18 \mathrm{mg}, 0.022 \mathrm{mmol})$ and $1 \mathrm{M} \mathrm{AcONa}$ in $\mathrm{MeOH}(4$ $\mathrm{mL})$. The reaction mixture was heated to reflux overnight. After cooling to room temperature, $\mathrm{CHCl}_{3}(60 \mathrm{~mL})$ was added and the mixture was filtered. Evaporation of the filtrate gave a residue, which was purified by silica gel chromatography $\left(\mathrm{CHCl}_{3} / \mathrm{MeOH}\right.$ $=9: 1)$ and then RP-HPLC $\left(\mathrm{MeCN} / \mathrm{H}_{2} \mathrm{O}=1: 1\right)$ to give $4.1 \mathrm{mg}$ of 13 (59\%). ${ }^{1} \mathrm{H}$ NMR (400 MHz, DMSO- $\left.d_{6}\right) \delta 9.35$ (s, 1H), $8.02(\mathrm{~d}, J=$ $8.8 \mathrm{~Hz}, 2 \mathrm{H}), 7.92(\mathrm{~d}, J=8.4 \mathrm{~Hz}, 1 \mathrm{H}), 7.47$ (d, $J=8.4 \mathrm{~Hz}, 1 \mathrm{H}), 7.44$ $(\mathrm{s}, 1 \mathrm{H}), 6.70(\mathrm{~d}, J=8.8 \mathrm{~Hz}, 2 \mathrm{H}), 5.69(\mathrm{~s}, 2 \mathrm{H}), 4.29(\mathrm{t}, J=5.6 \mathrm{~Hz}$, 2H), 4.18-3.82 (m, 4H), 3.64-3.06 (m, 6H), 2.72-1.68 (m, 6H). HRMS (ESI): $m / z$ calculated for $\mathrm{C}_{23} \mathrm{H}_{28} \mathrm{~N}_{5} \mathrm{NaO}_{2}{ }^{187} \mathrm{ReS}_{2}{ }^{+}[\mathrm{M}+\mathrm{Na}]^{+}$, 680.1134 ; found, 680.1134 .

\section{${ }^{99} \mathrm{~m}_{\text {Tc-labeling reaction }}$}

To a solution of sodium glucoheptonate dehydrate $(2.0 \mathrm{~g}, 7.0$ mmol) in $\mathrm{H}_{2} \mathrm{O}(25 \mathrm{~mL})$ was added $0.75 \mathrm{~mL}$ of an $\mathrm{SnCl}_{2} \cdot 2 \mathrm{H}_{2} \mathrm{O}$ solution [12 $\mathrm{mg}$ of tin(II) chloride dehydrate $(53 \mathrm{mmol})$ dissolved in $15 \mathrm{~mL}$ of $0.1 \mathrm{M} \mathrm{HCl}$ ]. This solution was adjusted to $\mathrm{pH}$ 8.5-9.0 using a small amount of $0.1 \mathrm{M} \mathrm{NaOH}$. After being lyophilized to give the pulverulent $\mathrm{Sn}$ glucoheptonate $(\mathrm{SnGH}) \mathrm{kit}, 1.0 \mathrm{mg}$ of this was weighed and added to an $\mathrm{Na}^{99 \mathrm{~m}} \mathrm{TcO}_{4}$ solution $(200 \mu \mathrm{L})$. The solution was reacted at room temperature for $10 \mathrm{~min}$ to give a ${ }^{99 m_{\text {TcGH }}}$ solution. A solution of the precursor $(7,8$, or 12) $(0.3$ $\mathrm{mg})$ in TFA $(400 \mu \mathrm{L})$ was mixed with triethylsilane $(20 \mu \mathrm{L})$, and the solvents were removed under a stream of argon gas. The residue was resolved in $\mathrm{MeCN}(100 \mu \mathrm{L})$, followed by the addition of $0.1 \mathrm{M} \mathrm{HCl}(10 \mu \mathrm{L})$ and the ${ }^{99 \mathrm{~m}} \mathrm{TcGH}$ solution $(100 \mu \mathrm{L})$. The reaction mixture was heated to $110^{\circ} \mathrm{C}$ for $20 \mathrm{~min}$. After cooling to room temperature, saturated $\mathrm{NaHCO}_{3}$ (aq.) $(30 \mu \mathrm{L})$ was added. The mixture was purified by RP-HPLC. The ${ }^{99 \mathrm{~m}}$ Tclabeled phenylquinoxaline complex was analyzed by analytical RP-HPLC on a Cosmosil $\mathrm{C}_{18}$ column $\left(5 \mathrm{C}_{18}\right.$-AR-II, $\left.4.6 \times 150 \mathrm{~mm}\right)$ with a solvent of $\mathrm{H}_{2} \mathrm{O} / \mathrm{MeCN}$ [11: 9 (0 min) to $1: 3$ (30 min)] as the mobile phase at a flow rate of $1.0 \mathrm{~mL} \mathrm{~min}^{-1}$. The radioactivity of the ${ }^{99 \mathrm{~m}}$ Tc-labeled form was recorded for $30 \mathrm{~min}$.

\section{Measurement of $\log P$}

The experimental determination of partition coefficients was performed in 1-octanol and phosphate-buffered saline (PBS) ( $\mathrm{pH}$ 7.4). The two phases were presaturated with each other. 1Octanol $(3.0 \mathrm{~mL})$ and PBS $(3.0 \mathrm{~mL})$ were pipetted into a $15 \mathrm{~mL}$ test tube containing the ${ }^{99 \mathrm{~m}} \mathrm{Tc}$ complex. The test tube was vortexed for $2 \mathrm{~min}$ and centrifuged (5 min, 4000g). Aliquots (500 $\mu \mathrm{L}$ ) from the 1-octanol and PBS phases were transferred into two test tubes for counting. One milliliter of the remaining 1-octanol phase, new 1-octanol $(2.0 \mathrm{~mL})$, and PBS $(3.0 \mathrm{~mL})$ were pipetted into a new test tube. The vortexing, centrifuging, and counting were repeated until consistent partition coefficient values were obtained (usually the sixth partition). The amount of radioactivity in each tube was measured with a $\gamma$ counter (Wallac 1470 Wizard; PerkinElmer, Massachusetts, U.S.A.). The partition coefficient was calculated using the equation: $\log P=\log \left[\right.$ count $_{1 \text {-octanol }} /$ count $\left._{\text {PBS }}\right]$.

\section{Binding assay using $A \beta(1-42)$ aggregates in solution}

A solid form of $A \beta(1-42)$ was purchased from the Peptide Institute (Osaka, Japan). Aggregation was carried out by gently dissolving the peptide $\left(0.25 \mathrm{mg} \mathrm{mL}^{-1}\right)$ in PBS ( $\left.\mathrm{pH} 7.4\right)$. The solution was incubated at $37{ }^{\circ} \mathrm{C}$ for $42 \mathrm{~h}$ with gentle and constant shaking. Aggregated $\mathrm{A} \beta(1-42)$ was used after being diluted to a concentration appropriate for the assays with PBS. The binding assay was performed by mixing $50 \mu \mathrm{L}$ of $\mathrm{A} \beta(1-42)$ aggregates (final conc., $0.125,1.25,2.5$, and $5.0 \mu \mathrm{g} \mathrm{mL}^{-1}$ ), $50 \mu \mathrm{L}$ of $\left[{ }^{99 \mathrm{~m}} \mathrm{Tc}\right] \mathbf{1 4},\left[{ }^{99 \mathrm{~m}} \mathrm{Tc}\right] \mathbf{1 5}$, or $\left[{ }^{99 \mathrm{~m}} \mathrm{Tc}\right] \mathbf{1 6}(8.3 \mathrm{kBq}$ in $30 \% \mathrm{EtOH})$, and $900 \mu \mathrm{L}$ of $30 \% \mathrm{EtOH}$. After incubation at room temperature for $3 \mathrm{~h}$, the mixture was filtered through Whatman GF/B filters (Whatman, Kent, U.K.) using a Brandel M-24 cell harvester (Brandel, Maryland, U.S.A.), and the radioactivity of the filters 
containing the bound ${ }^{99 \mathrm{~m}} \mathrm{Tc}$ complex was measured using a $\gamma$ counter (PerkinElmer).

\section{Competitive inhibition assay using $A \beta(1-42)$ aggregates in solution}

A mixture containing $50 \mu \mathrm{L}$ of Re complex (9 or 10) or 6-iodo-2(4'-dimethylamino)phenyl-imidazo[1,2-a]-pyridine (IMPY) (final conc., $10 \mathrm{pM}$ to $20 \mu \mathrm{M}$ in DMSO), $50 \mu \mathrm{L}$ of $\left[{ }^{125} \mathrm{I}\right] \mathrm{IMPY}$ (final conc., $2.5 \mathrm{kBq} \mathrm{mL}{ }^{-1}$ in $\left.\mathrm{EtOH}\right), 50 \mu \mathrm{L}$ of $\mathrm{A} \beta(1-42)$ aggregates (final conc., $0.125 \mu \mathrm{g} \mathrm{mL} \mathrm{mL}^{-1}$ ), and $850 \mu \mathrm{L}$ of $10 \%$ DMSO was incubated at room temperature for $3 \mathrm{~h}$. The mixture was then filtered through Whatman GF/B filters (Whatman) using a Brandel M-24 cell harvester (Brandel), and the radioactivity of the filters containing the bound ${ }^{125} \mathrm{I}$ ligand was measured using a $\gamma$ counter (PerkinElmer). Values for the half-maximal inhibitory concentration $\left(\mathrm{IC}_{50}\right)$ were determined from displacement curves of three independent experiments using GraphPad Prism 5.0 (GraphPad Software, Inc., California, U.S.A.), and those for the inhibition constant $\left(K_{\mathrm{i}}\right)$ were calculated using the Cheng-Prusoff equation: $K_{\mathrm{i}}=\mathrm{IC}_{50} /\left(1+[\mathrm{L}] / K_{\mathrm{d}}\right),{ }^{32}$ where $[\mathrm{L}]$ is the concentration of $\left[{ }^{125} \mathrm{I}\right] \mathrm{IMPY}$ used in the assay and $K_{\mathrm{d}}$ is the dissociation constant of IMPY $(4.2 \mathrm{nM}){ }^{30}$

\section{In vivo biodistribution assessment in normal mice}

A saline solution $(100 \mu \mathrm{L})$ of $\left[{ }^{99 \mathrm{~m}} \mathrm{Tc}\right] \mathbf{1 4}(20 \mathrm{kBq})$ containing EtOH $(20 \mu \mathrm{L})$ and Tween $80(0.1 \mathrm{mg})$ was injected directly into the tail vein of ddY mice (male, 5 weeks old). The mice were sacrificed at 2, 10, 30, and $60 \mathrm{~min}$ postinjection. The organs of interest were removed and weighed, and radioactivity was measured using a $\gamma$ counter (PerkinElmer). The $\%$ injected dose per $g$ (\% ID per g) of samples was calculated by comparing the sample counts with the count of the initial dose.

\section{Ex vivo autoradiography using Tg2576 and wild-type mice}

Tg2576 transgenic mice (female, 32 months old) and wild-type mice (female, 32 months old) were used as the AD model and age-matched control, respectively. A saline solution $(150 \mu \mathrm{L})$ of $\left[{ }^{99 \mathrm{~m}} \mathrm{Tc}\right] 14(25.9 \mathrm{MBq})$ containing EtOH $(30 \mu \mathrm{L})$ and Tween 80 $(0.15 \mathrm{mg})$ was injected through the tail vein. After the mice were sacrificed at $30 \mathrm{~min}$ postinjection by decapitation, the brain was immediately removed, embedded in Super Cryoembedding Medium (SCEM) compound (SECTION-LAB Co., Ltd., Hiroshima, Japan), and then frozen in a dry ice/hexane bath. Frozen sections were prepared at a $30 \mu \mathrm{m}$ thickness and exposed to a BAS imaging plate (Fuji Film, Tokyo, Japan) overnight. Autoradiographic images were obtained using a BAS5000 scanner system (Fuji Film). After autoradiographic examination, the same sections were stained by thioflavin-S to confirm the presence of $\mathrm{A} \beta$ depositions. For thioflavin-S fluorescent staining, the sections were immersed in a $100 \mu \mathrm{M}$ thioflavin-S solution containing $50 \% \mathrm{EtOH}$ for $3 \mathrm{~min}$, washed in $50 \% \mathrm{EtOH}$ for $1 \mathrm{~min}$ two times, and examined using a microscope (BIOREVO BZ-9000; Keyence Corp., Osaka, Japan) equipped with a GFP-BP filter set.

\section{Results and discussion}

\section{Chemistry}

The synthesis of the precursors for the ${ }^{99 \mathrm{~m}} \mathrm{Tc}$-labeling and the corresponding Re complex based on phenylquinoxaline is outlined in Scheme 1. A methoxy group of 6-methoxy-2chloroquinoxaline was converted to a hydroxyl group using $\mathrm{AlCl}_{3} /$ toluene according to our previous report, ${ }^{30}$ which afforded 3. The phenylquinoxaline backbone was formed by the Suzuki coupling reaction between 3 and the corresponding boronate ester, which afforded 4, 5, and 6 in 89, 61, and $10 \%$ yields, respectively. The thiol-protected chelation ligand (Trt-Boc-BAT) was synthesized as reported previously. ${ }^{21} \mathrm{~A}$ trimethylene group was introduced into Trt-Boc-BAT and $\mathbf{6}$ as a linker by reacting them with 1,3-dibromopropane, which afforded 2 and $\mathbf{1 1}$ in 26 and $62 \%$ yields, respectively. ${ }^{24}$ The precursors for ${ }^{99 \mathrm{~m}} \mathrm{Tc}-$ labeling, compounds $7, \mathbf{8}$, and $\mathbf{1 2}$, were synthesized by conjugating the chelating ligand and phenylquinoxaline scaffold. ${ }^{24}$ Technetium has no stable isotopes; therefore, direct structural characterization is very challenging. Since rhenium, the group VIIB congener of technetium, generally produces complexes with similar physical and biological properties to those of technetium, it is often used as a nonradioactive surrogate of technetium for large-scale synthesis and structural characterization. ${ }^{19,21,22,24-27}$ We prepared the corresponding Re complexes with phenylquinoxaline. After deprotection of the thiol groups of 7, 8, and 12 in TFA and triethylsilane, the Re complexes 9 (ReBAT-C3-PQ-1), 10 (Re-BAT-C3-PQ-2), and 13 (Re-BAT-C3-PQ-3) were synthesized, respectively, through a reaction with $\mathrm{ReOCl}_{3}\left(\mathrm{PPh}_{3}\right)_{2} .{ }^{1} \mathrm{H}$ NMR spectra and the HPLC profiles for three Re complexes $(\mathbf{9}, \mathbf{1 0}$, and 13) proved their high-level purity (ESI Fig. S1-S4†).

\section{${ }^{99 m}$ Tc-labeling reaction}

The ${ }^{99 \mathrm{~m}}$ Tc-labeling reaction was performed by a ligand exchange reaction employing the precursors 7,8 , and 12 with ${ }^{99 \mathrm{~m}} \mathrm{TcGH}$, which afforded $\left[{ }^{99 \mathrm{~m}} \mathrm{Tc}\right] \mathbf{1 4}\left({ }^{99 \mathrm{~m}} \mathrm{Tc}-\mathrm{BAT}-\mathrm{C} 3-\mathrm{PQ}-1\right)$, $\left[{ }^{99 \mathrm{~m}} \mathrm{Tc}\right] \mathbf{1 5}\left({ }^{99 \mathrm{~m}} \mathrm{Tc}-\mathrm{BAT}-\mathrm{C} 3-\mathrm{PQ}-2\right)$, and $\left[{ }^{99 \mathrm{~m}} \mathrm{Tc}\right] \mathbf{1 6}\left({ }^{99 \mathrm{~m}} \mathrm{Tc}-\mathrm{BAT}-\right.$ C3-PQ-3), respectively (Scheme 2). The radiochemical yields for $\left[{ }^{99 \mathrm{~m}} \mathrm{Tc}\right] \mathbf{1 4},\left[{ }^{99 \mathrm{~m}} \mathrm{Tc}\right] \mathbf{1 5}$, and $\left[{ }^{99 \mathrm{~m}} \mathrm{Tc}\right] \mathbf{1 6}$ were 56,62 , and $44 \%$, respectively. The resulting mixture was analyzed by RP-HPLC, showing that a single radioactive complex was formed with radiochemical purity higher than $99 \%$ after purification by HPLC. The radiochemical identity of the ${ }^{99 \mathrm{~m}}$ Tc complex was verified by comparative HPLC using the corresponding Re complex as a reference (Table 1). The retention times on RPHPLC (radioactivity) for $\left[{ }^{99 \mathrm{~m}} \mathrm{Tc}\right] \mathbf{1 4}$ ( $\left.{ }^{99 \mathrm{~m}} \mathrm{Tc}-\mathrm{BAT}-\mathrm{C} 3-\mathrm{PQ}-1\right)$, $\left[{ }^{99 \mathrm{~m}} \mathrm{Tc}\right] 15\left({ }^{99 \mathrm{~m}} \mathrm{Tc}-\mathrm{BAT}-\mathrm{C} 3-\mathrm{PQ}-2\right)$, and $\left[{ }^{99 \mathrm{~m}} \mathrm{Tc}\right] \mathbf{1 6}\left({ }^{99 \mathrm{~m}} \mathrm{Tc}-\mathrm{BAT}-\right.$ C3-PQ-3) were $23.3,16.6$, and $10.8 \mathrm{~min}$, respectively. Moreover, the retention times on RP-HPLC (absorption at $254 \mathrm{~nm}$ ) for 9 (Re-BAT-C3-PQ-1), 10 (Re-BAT-C3-PQ-2), and 13 (Re-BATC3-PQ-3) were $22.1,15.6$ and $10.1 \mathrm{~min}$, respectively. The retention times between ${ }^{99 \mathrm{~m}} \mathrm{Tc}$-labeled tracers and the corresponding Re complexes suggest that the desired ${ }^{99 \mathrm{~m}_{\mathrm{Tc}}} \mathrm{Tc}$ labeled phenylquinoxaline derivatives were successfully synthesized. 

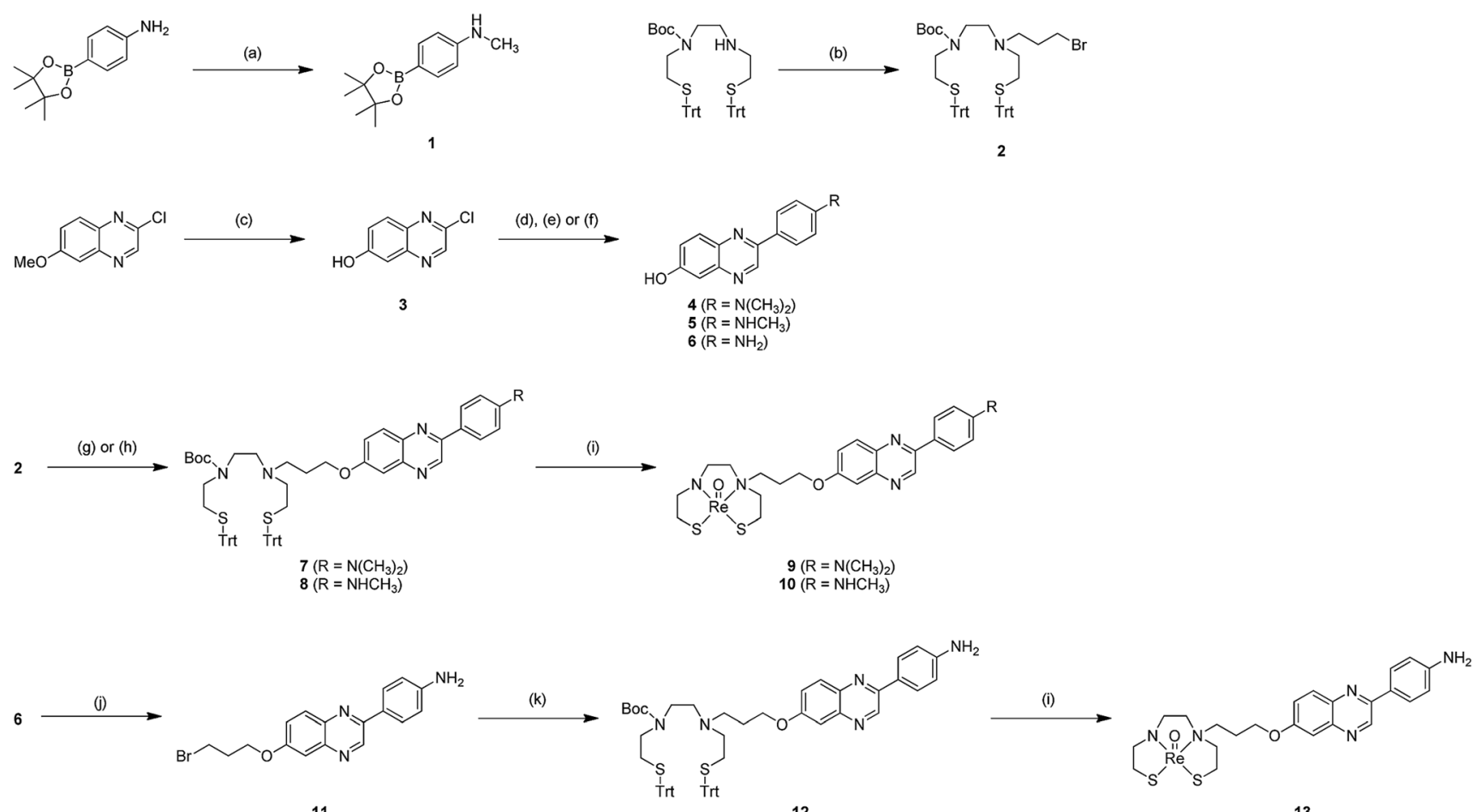

Scheme 1 Synthetic route for phenylquinoxaline derivatives. Reagents and conditions: (a) (1) paraformaldehyde, sodium methoxide, MeOH, reflux, (2) $\mathrm{NaBH}_{4}$, reflux; (b) 1,3-dibromopropane, $\mathrm{N}, \mathrm{N}$-diisopropylethylamine, DMF, $90{ }^{\circ} \mathrm{C}$; (c) $\mathrm{AlCl}$, toluene, $0{ }^{\circ} \mathrm{C}$ to $80{ }^{\circ} \mathrm{C}$; (d) $\mathrm{N}, \mathrm{N}$-dimethyl-4(4,4,5,5-tetramethyl-1,3,2-dioxaborolan-2-yl)aniline, $\mathrm{Pd}\left(\mathrm{PPh}_{3}\right)_{4}$, dioxane, $2 \mathrm{M} \mathrm{Na}_{2} \mathrm{CO}_{3}$ (aq.), reflux; (e) 1, $\mathrm{Pd}\left(\mathrm{PPh}_{3}\right)_{4}, \mathrm{dioxane}_{2} 2 \mathrm{M} \mathrm{Na} \mathrm{CO}_{3}(\mathrm{aq}$.), reflux; (f) 4-(4,4,5,5-tetramethyl-1,3,2-dioxaborolan-2-yl)aniline, $\mathrm{Pd}\left(\mathrm{PPh}_{3}\right)_{4}$, dioxane, $2 \mathrm{M} \mathrm{Na}_{2} \mathrm{CO}_{3}$ (aq.), reflux; (g) 4, $\mathrm{Cs}_{2} \mathrm{CO}_{3}, \mathrm{DMF}, 70{ }^{\circ} \mathrm{C}$; (h) 5, $\mathrm{Cs}_{2} \mathrm{CO}_{3}, \mathrm{DMF}, 70{ }^{\circ} \mathrm{C}$; (i) (1) triethylsilane, TFA, room temperature, (2) $\mathrm{ReOCl}_{3}\left(\mathrm{PPh}_{3}\right)_{2}, \mathrm{AcONa} \mathrm{CH}_{2} \mathrm{Cl}_{2}, \mathrm{MeOH}$, reflux; (j) 1,3-dibromopropane, $\mathrm{K}_{2} \mathrm{CO}_{3}, \mathrm{MeCN}$, reflux; (k) Trt-Boc-BAT, $\mathrm{N}, \mathrm{N}$-diisopropylethylamine, DMF, $110{ }^{\circ} \mathrm{C}$

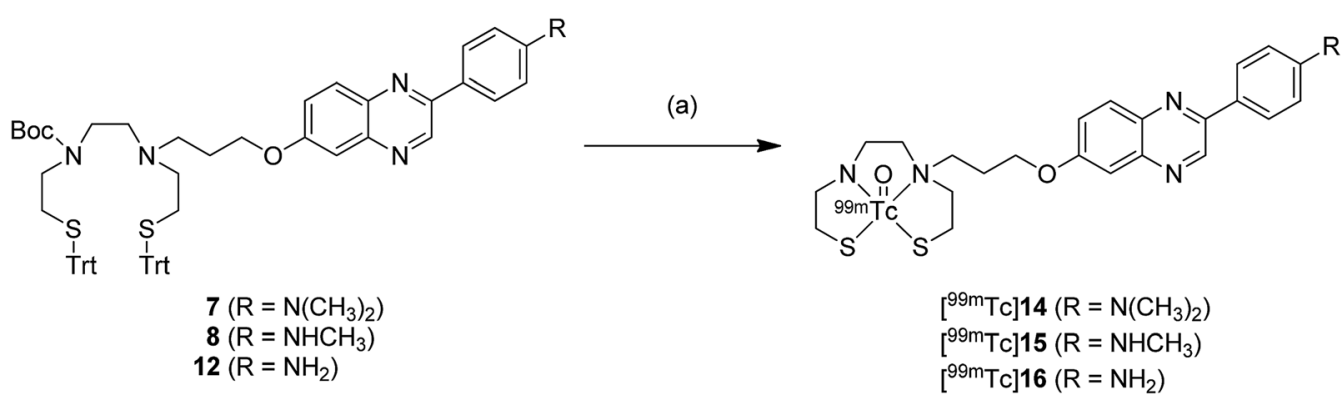

Scheme $2{ }^{99 m}$ Tc-labeling of phenylquinoxaline derivatives. Reagents and conditions: (a) (1) triethylsilane, TFA, room temperature, (2) ${ }^{99 \mathrm{~m}} \mathrm{Tc}$-glucoheptonate, $0.1 \mathrm{~N} \mathrm{HCl}, \mathrm{MeCN}, 110{ }^{\circ} \mathrm{C}$.

\section{Binding assay using $A \beta(1-42)$ aggregates in solution}

To evaluate the binding affinity for $A \beta(1-42)$ aggregates of $\left[{ }^{99 \mathrm{~m}} \mathrm{Tc}\right] \mathbf{1 4}\left({ }^{99 \mathrm{~m}} \mathrm{Tc}-\mathrm{BAT}-\mathrm{C} 3-\mathrm{PQ}-1\right),\left[{ }^{99 \mathrm{~m}} \mathrm{Tc}\right] \mathbf{1 5}\left({ }^{99 \mathrm{~m}} \mathrm{Tc}-\mathrm{BAT}-\mathrm{C} 3-\mathrm{PQ}-2\right)$,

Table 1 HPLC retention times of ${ }^{99 m} \mathrm{Tc} / \operatorname{Re}$ complexes ${ }^{a}$

\begin{tabular}{llll}
\hline Re complex & Retention time & ${ }^{99 \mathrm{~m}} \mathrm{Tc}$ complex & Retention time \\
\hline $\mathbf{9}$ & $22.1 \mathrm{~min}$ & {$\left[{ }^{99 \mathrm{~m}} \mathrm{Tc}\right] \mathbf{1 4}$} & $23.3 \mathrm{~min}$ \\
$\mathbf{1 0}$ & $\mathbf{1 5 . 6 \mathrm { min }}$ & {$\left[{ }^{99 \mathrm{~m}} \mathrm{Tc}\right] \mathbf{1 5}$} & $16.6 \mathrm{~min}$ \\
$\mathbf{1 3}$ & $10.1 \mathrm{~min}$ & {$\left[{ }^{99 \mathrm{~m}} \mathrm{Tc}\right] \mathbf{1 6}$} & $10.8 \mathrm{~min}$
\end{tabular}

${ }^{a}$ RP-HPLC using a solution of $\mathrm{H}_{2} \mathrm{O} / \mathrm{MeCN}[11: 9$ (0 min) to $1: 3$ (30 $\min )]$ as a mobile phase.

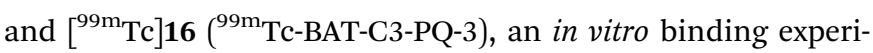
ment in solution was carried out. Fig. 2 shows the binding affinity of $\left[{ }^{99 \mathrm{~m}} \mathrm{Tc}\right] \mathbf{1 4},\left[{ }^{99 \mathrm{~m}} \mathrm{Tc}\right] \mathbf{1 5}$, and $\left[{ }^{99 \mathrm{~m}} \mathrm{Tc}\right] \mathbf{1 6}$ as specific $\mathrm{A} \beta(1-$ 42) aggregate-bound radioactivity (\%) at different concentrations of $A \beta(1-42)$ aggregates. The percent radioactivity of $\left[{ }^{99 \mathrm{~m}} \mathrm{Tc}\right]$

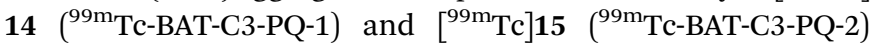
bound to aggregates increased dependent on the dose of $\mathrm{A} \beta(1-42)$, while $\left[{ }^{99 \mathrm{~m}} \mathrm{Tc}\right] 16\left({ }^{99 \mathrm{~m}} \mathrm{Tc}-\mathrm{BAT}-\mathrm{C} 3-\mathrm{PQ}-3\right)$ showed no marked affinity for the aggregates. In terms of $A \beta(1-42)$ aggregate-bound radioactivity, the derivatives ranked in the following order: $\left[{ }^{99 \mathrm{~m}} \mathrm{Tc}\right] \mathbf{1 4}>\left[{ }^{99 \mathrm{~m}} \mathrm{Tc}\right] \mathbf{1 5}>\left[{ }^{99 \mathrm{~m}} \mathrm{Tc}\right] \mathbf{1 6}$, at all concentrations of $A \beta(1-42)$ aggregates. The order in terms of the strength of binding corresponded with those of radioiodinated 


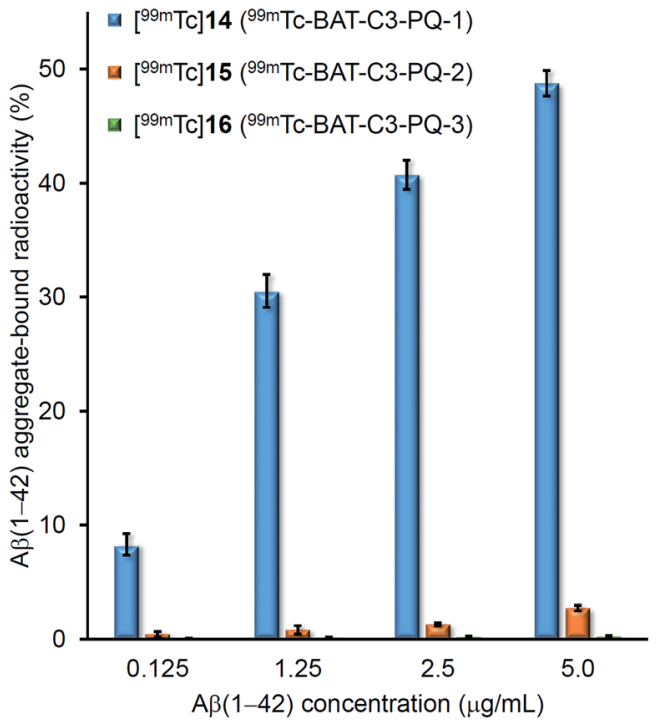

Fig. 2 Binding assay of ${ }^{99 m}$ Tc-labeled phenylquinoxaline derivatives using $A \beta(1-42)$ aggregates. Values are the mean \pm standard deviation of the mean of three independent experiments.

and radiofluorinated quinoxaline derivatives; in other words, the affinity increased in the order of the $N, N$-dimethylated derivative $>N$-monomethylated derivative $>$ primary amino derivative..$^{29,30}$

\section{Competitive inhibition assay using $A \beta(1-42)$ aggregates in solution}

Since $\left[{ }^{99 \mathrm{~m}} \mathrm{Tc}\right] \mathbf{1 4}$ and $\left[{ }^{99 \mathrm{~m}} \mathrm{Tc}\right] \mathbf{1 5}$ showed affinity for $\mathrm{A} \beta$ aggregates in the $A \beta(1-42)$ binding assay, quantitative binding affinity for $A \beta$ aggregates was evaluated with rhenium complexes 9 (ReBAT-C3-PQ-1) and 10 (Re-BAT-C3-PQ-2) according to conventional methods using $\left[{ }^{[25} \mathrm{I}\right] \mathrm{IMPY} .{ }^{33}$ Both Re complexes $\mathbf{9}$ and $\mathbf{1 0}$ inhibited the binding of $\left[{ }^{125} \mathrm{I}\right] \mathrm{IMPY}$ in a dose-dependent manner, with $K_{\mathrm{i}}$ values of 53.7 and $296 \mathrm{nM}$, respectively (Table 2). The affinity for $A \beta(1-42)$ aggregates of Re complexes well reflected that of the corresponding ${ }^{99 \mathrm{~m}} \mathrm{Tc}$ complexes, confirmed above. These Re complexes showed the $K_{\mathrm{i}}$ values, which were comparable to those of the corresponding Re complexes of the ${ }^{99 \mathrm{~m}} \mathrm{Tc}$-labeled probes reported previously $(13.6-393 \mathrm{nM}) .^{24,26,27}$ The binding affinity of the $N, N$-dimethylated derivative (9) was slightly lower than that of PIB (9.00 $\mathrm{nM})^{34}$ and IMPY $(12.3 \mathrm{nM})$, indicating that it may exhibit sufficient affinity for the imaging of $\mathrm{A} \beta(1-42)$ aggregates in vivo.

Table 2 Inhibition constants $\left(K_{\mathrm{i}}, \mathrm{nM}\right)$ for the binding of Re complexes and IMPY to $A \beta(1-42)$ aggregates determined using $\left[{ }^{125} \mathrm{I}\right] \mathrm{IMPY}$ as ligand

\begin{tabular}{lr}
\hline Compound & \multicolumn{1}{c}{$K_{\mathrm{i}}^{a}(\mathrm{nM})$} \\
\hline 9 (Re-BAT-C3-PQ-1) & $53.7 \pm 8.77$ \\
10 (Re-BAT-C3-PQ-2) & $296 \pm 26.0$ \\
IMPY & $12.3 \pm 1.52$
\end{tabular}

${ }^{a}$ Values are the mean \pm standard error of the mean for six independent experiments.
However, the $K_{\mathrm{i}}$ values of these Re complexes were higher than those of quinoxaline derivatives with introduced iodine (4.1 $\mathrm{nM})$ and fluorine ( $0.895 \mathrm{nM}$ ) reported previously. ${ }^{29,30}$ This result suggests that the introduction of the bulky ${ }^{99 \mathrm{~m}} \mathrm{Tc}-\mathrm{BAT}$ complex into the phenylquinoxaline scaffold interferes with the binding to $A \beta(1-42)$ aggregates, as shown in some reports on other $A \beta$ imaging probes conjugated with the ${ }^{99 \mathrm{~m}}$ Tc-BAT complex. ${ }^{24}$ According to the result of binding affinity for $A \beta(1-42)$ aggregates in vitro, further studies were conducted using $\left[{ }^{99 \mathrm{~m}} \mathrm{Tc}\right] \mathbf{1 4}$ $\left({ }^{99 \mathrm{~m}} \mathrm{Tc}-\mathrm{BAT}-\mathrm{C} 3-\mathrm{PQ}-1\right)$ with the highest binding affinity.

\section{In vivo biodistribution assessment in normal mice}

To evaluate the brain uptake of [ $\left.{ }^{99 \mathrm{~m}} \mathrm{Tc}\right] \mathbf{1 4}\left({ }^{99 \mathrm{~m}} \mathrm{Tc}-\mathrm{BAT}-\mathrm{C} 3-\mathrm{PQ}-1\right)$, a biodistribution experiment was performed with normal mice (Table 3). An ideal A $\beta$ imaging probe should show high-level efficiency along with BBB penetration to deliver an adequate dose into the brain, and then achieve rapid clearance of the non-bound tracer from the brain to reduce the background signal in the AD brain. Previous studies suggested that the optimal measured $\log P$-value of compounds to pass freely across the BBB ranged from 0.9 to $2.5 .^{35}$ The $\log P$-value for $\left[{ }^{99 \mathrm{~m}} \mathrm{Tc}\right] 14$ was 2.45 , indicating that this complex might penetrate the BBB. $\left[{ }^{99 \mathrm{~m}} \mathrm{Tc}\right] \mathbf{1 4}$ showed the highest initial uptake at 2 min postinjection ( $0.88 \%$ ID per g), which was comparable or slightly lower than those of ${ }^{99 \mathrm{~m}}$ Tc-labeled probes reported previously $(0.2-1.80 \%$ ID per $g) \cdot{ }^{19-22,24-27}$ The radioactivity of $\left[{ }^{99 \mathrm{~m}} \mathrm{Tc}\right] \mathbf{1 4}$ in the brain was rapidly eliminated $(0.25 \%$ ID per $\mathrm{g}$ at $60 \mathrm{~min}$ postinjection). The $\mathrm{brain}_{2} \mathrm{~min} / \mathrm{brain}_{60} \mathrm{~min}$ ratio is generally used as an index for evaluating pharmacokinetics in vivo. The brain $_{2} \mathrm{~min} / \mathrm{brain}_{60 \mathrm{~min}}$ ratio of ${ }^{99 \mathrm{~m}} \mathrm{Tc}-\mathrm{BAT}-\mathrm{C} 3-\mathrm{PQ}-1$ was 3.52 , indicating that it displayed one of the best profiles of radioactivity in the brain among ${ }^{99 \mathrm{~m}} \mathrm{Tc}$ complexes reported previously. ${ }^{19-22,24-27}$ Although the brain $_{2}$ min $/$ brain $_{60}$ min ratio of ${ }^{99 \mathrm{~m}}$ Tc-BAT-C3-PQ-1 was lower than those of $\left[{ }^{11} \mathrm{C}\right] \mathrm{PIB}(11.7)^{6}$ and $\left[{ }^{123} \mathrm{I}\right] \mathrm{IMPY}(14.4),{ }^{33}$ it was comparable to that of $\left[{ }^{18} \mathrm{~F}\right]$ florbetapir (3.80). ${ }^{30}$ These indicate its promising property for the imaging

Table 3 Biodistribution of radioactivity after intravenous injection of $\left[{ }^{99 \mathrm{~m}} \mathrm{Tc}\right] 14\left({ }^{99 \mathrm{~m}} \mathrm{Tc}-\mathrm{BAT}-\mathrm{C} 3-\mathrm{PQ}-1\right)$ in normal mice ${ }^{a}$

Time after injection (min)

\begin{tabular}{lllll} 
Tissue & 2 & 10 & 30 & 60 \\
\hline Blood & $10.97(0.90)$ & $5.39(0.32)$ & $3.04(0.20)$ & $2.38(0.17)$ \\
Liver & $27.07(0.60)$ & $29.66(1.96)$ & $31.41(1.63)$ & $26.25(1.47)$ \\
Kidney & $12.51(1.18)$ & $9.12(0.33)$ & $6.47(0.36)$ & $4.84(0.58)$ \\
Intestine & $2.35(0.33)$ & $6.06(0.48)$ & $14.22(1.96)$ & $16.88(2.92)$ \\
Spleen & $4.53(1.23)$ & $3.32(0.19)$ & $2.38(0.26)$ & $1.84(0.25)$ \\
Pancreas & $4.92(0.22)$ & $3.95(0.51)$ & $2.82(0.19)$ & $2.09(0.93)$ \\
Heart & $10.40(1.00)$ & $4.17(0.25)$ & $2.64(0.18)$ & $1.88(0.21)$ \\
Lung $_{\text {Stomach }}^{b}$ & $12.72(1.12)$ & $6.82(0.50)$ & $4.97(0.56)$ & $3.38(0.57)$ \\
Brain $^{1.90(0.17)}$ & $4.89(1.31)$ & $8.44(1.90)$ & $6.79(0.82)$ \\
& $0.88(0.08)$ & $0.77(0.08)$ & $0.52(0.03)$ & $0.25(0.02)$
\end{tabular}

${ }^{a}$ Expressed as \% injected dose per gram of tissue. Each value is the mean (standard deviation) of five animals at each interval.

${ }^{b}$ Expressed as \% injected dose. 

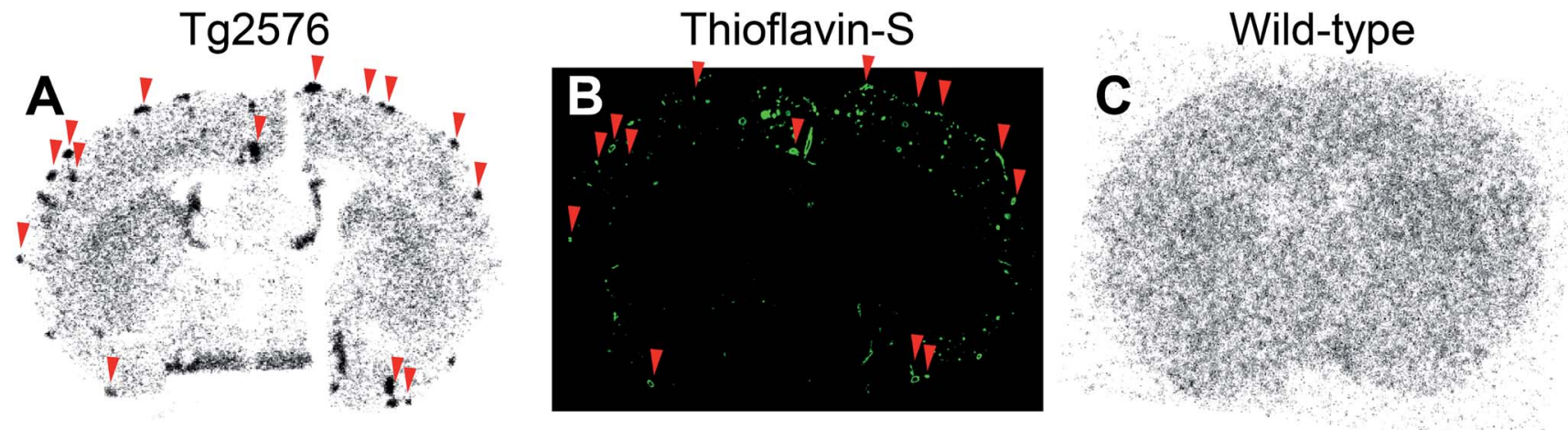

Fig. 3 Ex vivo autoradiograms from a Tg2576 mouse (A) and a wild-type mouse (C) with [ ${ }^{99 m}$ Tc]14 $\left({ }^{99 m}\right.$ Tc-BAT-C3-PQ-1). The same sections are also stained with thioflavin-S (B).

of $A \beta$ in the brain. Unfortunately, radioactivity in the stomach suggests the partial decomposition to pertechnetate in vivo.

\section{Ex vivo autoradiography using Tg2576 and wild-type mice}

According to the results of the binding affinity assay in vitro and biodistribution in normal mice, we further evaluated the potential of $\left[{ }^{99 \mathrm{~m}} \mathrm{Tc}\right] \mathbf{1 4}\left({ }^{99 \mathrm{~m}} \mathrm{Tc}-\mathrm{BAT}-\mathrm{C} 3-\mathrm{PQ}-1\right)$ for imaging A $\beta$ plaques in the $\mathrm{AD}$ model mouse. An ex vivo autoradiographic examination was carried out using Tg2576 transgenic mouse (Fig. 3). Since Tg2576 mice are known to overproduce $A \beta$ aggregates in the brain, they have been commonly used to evaluate the specific binding to $A \beta$ aggregates in experiments in vitro and in vivo. ${ }^{24,30,36}$ The brain was removed at $30 \mathrm{~min}$ postinjection for autoradiography. $\left[{ }^{99 \mathrm{~m}} \mathrm{Tc}\right] \mathbf{1 4}$ showed intensive radioactive spots in sections from the Tg2576 mouse, but not the age-matched control (Fig. 3A and C). Furthermore, these spots corresponded with $A \beta$ depositions confirmed by fluorescent staining in the same sections with thioflavin-S, a histochemical dye commonly used to stain $A \beta$ plaques (Fig. 3B, red arrowheads). This suggests that ${ }^{99 \mathrm{~m}} \mathrm{Tc}-\mathrm{BAT}-\mathrm{C} 3-\mathrm{PQ}-1$ had sufficient properties to detect $A \beta$ plaques in the transgenic mouse, although it displayed a lower affinity for $\mathrm{A} \beta$ aggregates and lower brain uptake in normal mice than the clinically utilized probes, such as $\left[{ }^{11} \mathrm{C}\right] \mathrm{PIB}$ and $\left[{ }^{18} \mathrm{~F}\right]$ florbetapir. In addition, the nonspecific accumulation of radioactivity within the white matter, which was demonstrated in our previous reports, ${ }^{30}$ was not observed for ${ }^{99 \mathrm{~m}}$ Tc-BAT-C3-PQ-1, as shown in Fig. 3A and C, probably due to its low brain uptake. However, some $A \beta$ depo-

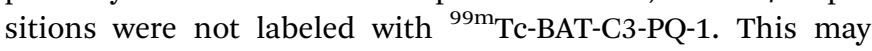
derive from its low brain uptake, low affinity, and low in vivo stability, which are insufficient to bind to $A \beta$ aggregates deposited in the whole brain. Therefore, further modifications are required to improve the properties of ${ }^{99 \mathrm{~m}} \mathrm{Tc}$-labeled phenylquinoxaline derivatives for imaging $\mathrm{A} \beta$ plaques in $\mathrm{AD}$ brains.

\section{Conclusion}

We successfully synthesized three ${ }^{99 m}$ Tc-labeled phenylquinoxaline derivatives and their corresponding Re complexes. Among them, ${ }^{99 \mathrm{~m}} \mathrm{Tc}-\mathrm{BAT}-\mathrm{C} 3-\mathrm{PQ}-1$ and its corresponding Re complex showed sufficient binding affinity for $\mathrm{A} \beta$ aggregates in an in vitro binding assay. An in vivo biodistribution study with ${ }^{99} \mathrm{~m}$ Tc-BAT-C3-PQ-1 in normal mice indicated its moderate initial brain uptake and reasonable clearance from the brain. Moreover, it showed extensive labeling of $A \beta$ plaques in the transgenic mouse brain. Taken together, the findings in the present study provide important information on developing clinically useful ${ }^{99 \mathrm{~m}} \mathrm{Tc}$-labeled $\mathrm{A} \beta$ imaging probes for the diagnosis of $\mathrm{AD}$ based on quinoxaline derivatives. Additional modifications to further improve the pharmacokinetics in the brain and the binding affinity for $\mathrm{A} \beta$ aggregates of ${ }^{99 \mathrm{~m}} \mathrm{Tc}$ complexes are underway.

\section{Acknowledgements}

The study was supported by a Grant-in-Aid for Scientific Research (B) (Grant Number 26293274), the Nakatani Foundation for Advancement of Measuring Technologies in Biomedical Engineering, Japan Research Foundation for Clinical Pharmacology, and a JSPS Research Fellowship for Young Scientists (16J05493).

\section{References}

1 A. Nordberg, Lancet Neurol., 2004, 3, 519-527.

2 R. L. Nussbaum and C. E. Ellis, N. Engl. J. Med., 2003, 348, 1356-1364.

3 E. Giacobini and R. E. Becker, J. Alzheimer's Dis., 2007, 12, 3752.

4 S. Hatashita, H. Yamasaki, Y. Suzuki, K. Tanaka, D. Wakebe and H. Hayakawa, Eur. J. Nucl. Med. Mol. Imaging, 2014, 41, 290-300.

5 W. E. Klunk, H. Engler, A. Nordberg, Y. Wang, G. Blomqvist, D. P. Holt, M. Bergstrom, I. Savitcheva, G. F. Huang, S. Estrada, B. Ausen, M. L. Debnath, J. Barletta, J. C. Price, J. Sandell, B. J. Lopresti, A. Wall, P. Koivisto, G. Antoni, C. A. Mathis and B. Langstrom, Ann. Neurol., 2004, 55, 306-319.

6 C. A. Mathis, Y. Wang, D. P. Holt, G. F. Huang, M. L. Debnath and W. E. Klunk, J. Med. Chem., 2003, 46, 2740-2754.

7 R. Ni, P. G. Gillberg, A. Bergfors, A. Marutle and A. Nordberg, Brain, 2013, 136, 2217-2227. 
8 K. J. Lin, W. C. Hsu, I. T. Hsiao, S. P. Wey, L. W. Jin, D. Skovronsky, Y. Y. Wai, H. P. Chang, C. W. Lo, C. H. Yao, T. C. Yen and M. P. Kung, Nucl. Med. Biol., 2010, 37, 497-508.

9 D. F. Wong, P. B. Rosenberg, Y. Zhou, A. Kumar, V. Raymont, H. T. Ravert, R. F. Dannals, A. Nandi, J. R. Brasic, W. Ye, J. Hilton, C. Lyketsos, H. F. Kung, A. D. Joshi, D. M. Skovronsky and M. J. Pontecorvo, J. Nucl. Med., 2010, 51, 913-920.

10 R. Lundqvist, J. Lilja, B. A. Thomas, J. Lotjonen, V. L. Villemagne, C. C. Rowe and L. Thurfjell, J. Nucl. Med., 2013, 54, 1472-1478.

11 N. Nelissen, K. Van Laere, L. Thurfjell, R. Owenius, M. Vandenbulcke, M. Koole, G. Bormans, D. J. Brooks and R. Vandenberghe, J. Nucl. Med., 2009, 50, 1251-1259.

12 G. A. Becker, M. Ichise, H. Barthel, J. Luthardt, M. Patt, A. Seese, M. Schultze-Mosgau, B. Rohde, H. J. Gertz, C. Reininger and O. Sabri, J. Nucl. Med., 2013, 54, 723-731.

13 W. Zhang, S. Oya, M. P. Kung, C. Hou, D. L. Maier and H. F. Kung, Nucl. Med. Biol., 2005, 32, 799-809.

14 H. F. Kung, M. P. Kung, Z. P. Zhuang, C. Hou, C. W. Lee, K. Plössl, B. Zhuang, D. M. Skovronsky, V. M. Lee and J. Q. Trojanowski, Mol. Imaging Biol., 2003, 5, 418-426.

15 W. Qu, M. P. Kung, C. Hou, T. E. Benedum and H. F. Kung, J. Med. Chem., 2007, 50, 2157-2165.

16 M. Ono, Y. Cheng, H. Kimura, H. Watanabe, K. Matsumura, M. Yoshimura, S. Iikuni, Y. Okamoto, M. Ihara, R. Takahashi and H. Saji, PLoS One, 2013, 8, e74104.

17 C. J. Chen, K. Bando, H. Ashino, K. Taguchi, H. Shiraishi, K. Shima, O. Fujimoto, C. Kitamura, S. Matsushima, K. Uchida, Y. Nakahara, H. Kasahara, T. Minamizawa, C. Jiang, M. R. Zhang, M. Ono, M. Tokunaga, T. Suhara, M. Higuchi, K. Yamada and B. Ji, J. Nucl. Med., 2015, 56, 120-126.

18 Y. Maya, Y. Okumura, R. Kobayashi, T. Onishi, Y. Shoyama,

O. Barret, D. Alagille, D. Jennings, K. Marek, J. Seibyl, G. Tamagnan, A. Tanaka and Y. Shirakami, Brain, 2016, 139, 193-203.

19 Z. P. Zhuang, M. P. Kung, C. Hou, K. Ploessl and H. F. Kung, Nucl. Med. Biol., 2005, 32, 171-184.

20 K. Serdons, T. Verduyckt, J. Cleynhens, C. Terwinghe, L. Mortelmans, G. Bormans and A. Verbruggen, Bioorg. Med. Chem. Lett., 2007, 17, 6086-6090.
21 M. Ono, R. Ikeoka, H. Watanabe, H. Kimura, T. Fuchigami, M. Haratake, H. Saji and M. Nakayama, ACS Chem. Neurosci., 2010, 1, 598-607.

22 M. Ono, R. Ikeoka, H. Watanabe, H. Kimura, T. Fuchigami, M. Haratake, H. Saji and M. Nakayama, Bioorg. Med. Chem. Lett., 2010, 20, 5743-5748.

23 M. Sagnou, D. Benaki, C. Triantis, T. Tsotakos, V. Psycharis, C. P. Raptopoulou, I. Pirmettis, M. Papadopoulos and M. Pelecanou, Inorg. Chem., 2011, 50, 1295-1303.

24 Y. Cheng, M. Ono, H. Kimura, M. Ueda and H. Saji, J. Med. Chem., 2012, 55, 2279-2286.

25 M. Ono, Y. Fuchi, T. Fuchigami, N. Kobashi, H. Kimura, M. Haratake, H. Saji and M. Nakayama, ACS Med. Chem. Lett., 2010, 1, 443-447.

26 Y. Yang, M. Cui, B. Jin, X. Wang, Z. Li, P. Yu, J. Jia, H. Fu, H. Jia and B. Liu, Eur. J. Med. Chem., 2013, 64, 90-98.

27 X. Wang, M. Cui, J. Jia and B. Liu, Eur. J. Med. Chem., 2015, 89, 331-339.

28 X. Wang, M. Cui, P. Yu, Z. Li, Y. Yang, H. Jia and B. Liu, Bioorg. Med. Chem. Lett., 2012, 22, 4327-4331.

29 M. Cui, M. Ono, H. Kimura, B. Liu and H. Saji, Bioorg. Med. Chem. Lett., 2011, 21, 4193-4196.

30 M. Yoshimura, M. Ono, K. Matsumura, H. Watanabe, H. Kimura, M. Cui, Y. Nakamoto, K. Togashi, Y. Okamoto, M. Ihara, R. Takahashi and H. Saji, ACS Med. Chem. Lett., 2013, 4, 596-600.

31 P. Yu, M. Cui, X. Wang, X. Zhang, Z. Li, Y. Yang, J. Jia, J. Zhang, M. Ono, H. Saji, H. Jia and B. Liu, Eur. J. Med. Chem., 2012, 57, 51-58.

32 Y. Cheng and W. H. Prusoff, Biochem. Pharmacol., 1973, 22, 3099-3108.

33 M. P. Kung, C. Hou, Z. P. Zhuang, B. Zhang, D. Skovronsky, J. Q. Trojanowski, V. M. Lee and H. F. Kung, Brain Res., 2002, 956, 202-210.

34 M. Ono, Y. Cheng, H. Kimura, M. Cui, S. Kagawa, R. Nishii and H. Saji, J. Med. Chem., 2011, 54, 2971-2979.

35 D. D. Dishino, M. J. Welch, M. R. Kilbourn and M. E. Raichle, J. Nucl. Med., 1983, 24, 1030-1038.

36 A. Alpar, U. Ueberham, M. K. Bruckner, G. Seeger, T. Arendt and U. Gartner, Brain Res., 2006, 1099, 189-198. 